Available online on 15.06.2021 at http://jddtonline.info
Copyright ( 92021 The Author(s): This is an open-access article distributed under the terms of the CC BY-NC
4.0 which permits unrestricted use, distribution, and reproduction in any medium for non-commercial use
provided the original author and source are credited

Open Access Full Text Article

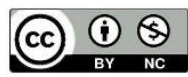

Research Article

\title{
Estimation of Protein / Creatinine Ration in Pre Eclampsia with Single Voided Urine Sample Compare with 24 Hours Urine Protein
}

\author{
Khatun Tarannum ${ }^{1 *}$, Ghimire Kritanjali ${ }^{1}$, Alam Shahid ${ }^{2}$ \\ ${ }^{1}$ Department of Obstetrics \& Gynaecology, National Medical College \& Teaching Hospital, Birgunj, Nepal \\ ${ }^{2}$ Department of Surgery, National Medical College \& Teaching Hospital, Birgunj, Nepal
}

Article Info:
Cite this article as:
Khatun T, Ghimire K, Alam S, Estimation of Protein /
Creatinine Ration in Pre Eclampsia with Single Voided
Urine Sample Compare with 24 Hours Urine Protein ,
Journal of Drug Delivery and Therapeutics. 2021;
11(3-S):35-47
DoI: http://dx.doi.org/10.22270/jddt.v11i3-S.4825

*Address for Correspondence:

Dr. Tarannum Khatun, Department of Obstetrics \& Gynaecology, National Medical College Teaching Hospital, Birgunj, Nepal.

Email: drtarannumnp@gmail.com

\section{Abstract}

\begin{abstract}
Background: Preeclampsia is characterized by hypertension and proteinuria with the onset after 20 weeks of gestation. Globally $14.5 \%$ of maternal death is due to preeclampsia with fetal complications. National Record of Family Health Division Nepal shows prevalence rate of preeclampsia as $8.5 \%$. The gold standard 24 hours urine protein evaluation test is time consuming for the diagnosis of preeclampsia and can increase complications to mother and fetus. Instant diagnosis and prompt management is needed. Objective of this study was to determine the accuracy of urinary protein/creatinine $(\mathrm{P} / \mathrm{C})$ ratio test and correlate random urinary $(\mathrm{P} / \mathrm{C})$ ratio with twenty-four hours urinary protein in detecting preeclampsia.
\end{abstract}

Methods: A cross sectional study was carried out conveniently selecting 130 samples of preeclampsia from Obstetrics and Gynaecology Department of National Medical College Teaching Hospital, Birgunj, Nepal. Out of 130 samples all met the inclusion criteria. Both twenty-four hours urine protein and $\mathrm{P} / \mathrm{C}$ ratio were performed for each case. Correlation between two tests and accuracy of the test was performed using SPSS V 16.

Results: This study showed protein creatinine ratio is as capable as 24 hours protein urine to diagnose pregnant mother with preeclampsia. Spot $\mathrm{P} / \mathrm{C}$ ratio provides effortless result with high validity and reliability.

Conclusion: This study showed protein creatinine ratio is as capable as 24 hours protein urine to diagnose pregnant mother with preeclampsia. Spot $\mathrm{P} / \mathrm{C}$ ratio provides effortless result with high validity and reliability.

Keywords: Preeclampsia, 24 hours urinary protein, Receiver Operator characteristic curve (ROC), Area under the curve (AUC)

\section{INTRODUCTION}

Preeclampsia is the most common medical complication of pregnancy. It is a multisystem disorder among pregnant women of gestational age more than 20 weeks which is associated with reduced organ perfusion resulting from vasospasm and endothelial activation with systolic and diastolic blood pressure more than 140 and $90 \mathrm{~mm}$ of $\mathrm{Hg}$ respectively measured in two different episodes (four hours apart) in previously normotensive woman, along with proteinuria $\geq 300 \mathrm{mg} /$ day on 24 hours urine protein excretion or $\mathrm{P} / \mathrm{C}$ ratio $\geq 0.3$ or Dipstick +1 persistent in random urine sample. ${ }^{1}$

Evolution in the medical field over many decades has comparatively declined morbidity and mortality but still even after medical advancement preeclampsia is prime cause for the maternal mortality and morbidity. Many epidemiological clinical studies have been conducted worldwide, still the prevalence of clinical preeclampsia remains difficult to determine. Preeclampsia comprise of 2 to $8 \%$ of all pregnancies. ${ }^{2}$ WHO explains about $14.5 \%$ of maternal deaths are encountered due to hypertensive disorders in pregnancy in southeast asia. ${ }^{3}$ Preeclampsia/eclampsia (18.2\%) is the third leading cause of maternal mortality after obstetric hemorrhage (38.6\%) and infection during pregnancy $(26.4 \%)$ in low and middleincome countries. ${ }^{4}$ In rural Nepal preeclampsia is considered as one of the leading cause of maternal mortality. ${ }^{5}$ It also affects fetus with poor fetal outcome leading to preterm delivery and intrauterine growth retardation (IUGR) which eventually increases fetal mortality. 6,7

In preeclampsia, etiology and pathophysiology remain unknown. According to various hypothesis postulated abnormal and incomplete trophoblastic invasion of the spiral arteries, endogenous hormones, nutrition, immunological factors, familial history are the major etiology identified. Preeclampsia is a result of severe vasospasm and endothelial dysfunction consecutively it leads to reduction in utero placental circulation, reduced renal and cerebral perfusion. In normal pregnancy, reduction of renal afferent and efferent resistance leads to increased glomerular filtration rate (GFR) 
and increased renal blood flow. Whereas in preeclampsia , increased resistance in renal afferent arterioles leads to decrease in GFR and renal blood flow. Consecutively, spasm of afferent arterioles of glomerulus leads to the increase excretion of urinary protein leading to glomerular endotheliosis. Changes in the endothelium and increased capillary permeability results in more protein leakage. 2,8

Proteinuria is the urinary excretion of protein measured by various quantification method which has a diagnostic and prognostic importance and is used in assessment of the effectiveness of management strategies. Degree of proteinuria is the indicative marker for the renal involvement. Proteinuria is a criteria to classify the severity of preeclampsia. $^{9}$ Proteinuria denotes considerable possibility of both fetal and maternal complications. Therefore, early detection and prompt diagnosis is important for maternal and fetal outcome.

The gold standard technique to quantify total urinary protein is by measurement of urinary protein collected over 24 hours. ${ }^{10}$ Excretion of urinary protein more than $300 \mathrm{mg}$ over 24 hours collection is considered proteinuria for preeclampsia. In preeclamptic patients main justifying reason behind 24 hours urinary collection is change in urinary protein concentration which might not quantify actual concentration of protein by random urine collection. Although it is the gold standard test there are some demerits. It is time consuming, patient compliance is less which limits its clinical usefulness. During 24 hours of duration patient sometime deliver before completion of the whole procedure. ${ }^{11,12}$

Urinary dipstick is another method to detect proteinuria from random voided urinary samples. It is commonly used screening method to quantify urinary protein amount with prompt, effortless and valid result.13 It is a simple process with sensitivity up to $97 \%$ shown in one of the study, ${ }^{14}$ whereas other study suggest dipstick as faulty predictor of 24 hours urinary protein.15 However, there is limited evidence and comparison between these tests in our literature.

Urinary protein/creatinine $(\mathrm{P} / \mathrm{C})$ ratio has been well established diagnostic tool for the measurement of proteinuria. ${ }^{16}$ Single voided urinary P/C ratio is adopted since it is considered that protein and creatinine are two content that will cancel out the time factor therefore gives result equivalent to 24 hours urinary protein. ${ }^{17}$ This test has a merit that it is accurate, removes sampling error since only a single specimen is required and can be done in any trimester. Regarding quantifying the proteinuria some studies has concluded P/C ratio quantified from random urine correlated excellently with 24 hours urinary protein. 18,19

Preeclampsia has been life-threatening to the patient with adding extra economic burden. Taking 24 hours in detection can increase morbidities and mortalities. Early detection and prompt diagnosis can save both maternal and child outcome. However, there is limited research on trustworthiness of random urine $\mathrm{P} / \mathrm{C}$ ratio. This study would provide clear evidence to make evidence-based policy regarding use of single random urine $\mathrm{P} / \mathrm{C}$ ratio. Therefore, this study was conducted to quantify the $\mathrm{P} / \mathrm{C}$ ratio in single urine which predicts amount of protein and compare the value with 24 hours urinary protein in patients with preeclampsia and its complications.

Main aim to this studies to determine the relation of random urinary $\mathrm{P} / \mathrm{C}$ ratio and 24 hours urinary protein in detecting proteinuria among pregnant women with preeclampsia.

And to correlate random urinary $\mathrm{P} / \mathrm{C}$ ratio with 24 hours urinary protein in detecting proteinuria among pregnant women with preeclampsia.

To find the accuracy of $\mathrm{P} / \mathrm{C}$ ratio in random urine samples for quantification of proteinuria among the pregnant women with preeclampsia.

\section{MATERIAL AND METHOD}

This is Quantitative and Cross-sectional study

\section{Study population/ sampling frame}

- All hospitalized pregnant women with Hypertension with proteinuria.

\section{Study Site}

- $\quad$ Study carried out at the Department of Gynaecology and Obstetrics, National Medical College and Teaching Hospital, Birgunj, Nepal. Selection was done in the medical college because it is a tertiary level hospital with a catchment area of around ten districts of Nepal and two districts of India.

- $\quad$ Non probability (purposive sampling)

\section{Sample size}

- Sample size was 119.5 taking $8.5 \%$ prevalence of preeclampsia

$$
\begin{gathered}
n=\frac{Z^{2} x P(1-P)}{d^{2}} \\
n=\frac{(1.96) 2 \times 0.085 \times 0.915}{0.05^{2}}=119.5 \\
\mathrm{n}=\text { sample size } \\
\mathrm{Z}=\text { level of confidence at } 95 \%(1.96) \\
\mathrm{P}=\text { Prevalence }(8.5 \%)^{5} \\
\mathrm{~d}=\text { degree of freedom } 5 \%
\end{gathered}
$$

\section{Inclusion criteria}

a. Pregnant women who developed hypertension after 20 weeks of gestation.

b. Proteinuria $(\geq 1+)$.

\section{Exclusion criteria}

Pregnant women with;

a. Pre-existing renal diseases with or without proteinuria

b. Chronic hypertension

c. Diabetes mellitus

d. Urinary Tract Infection 


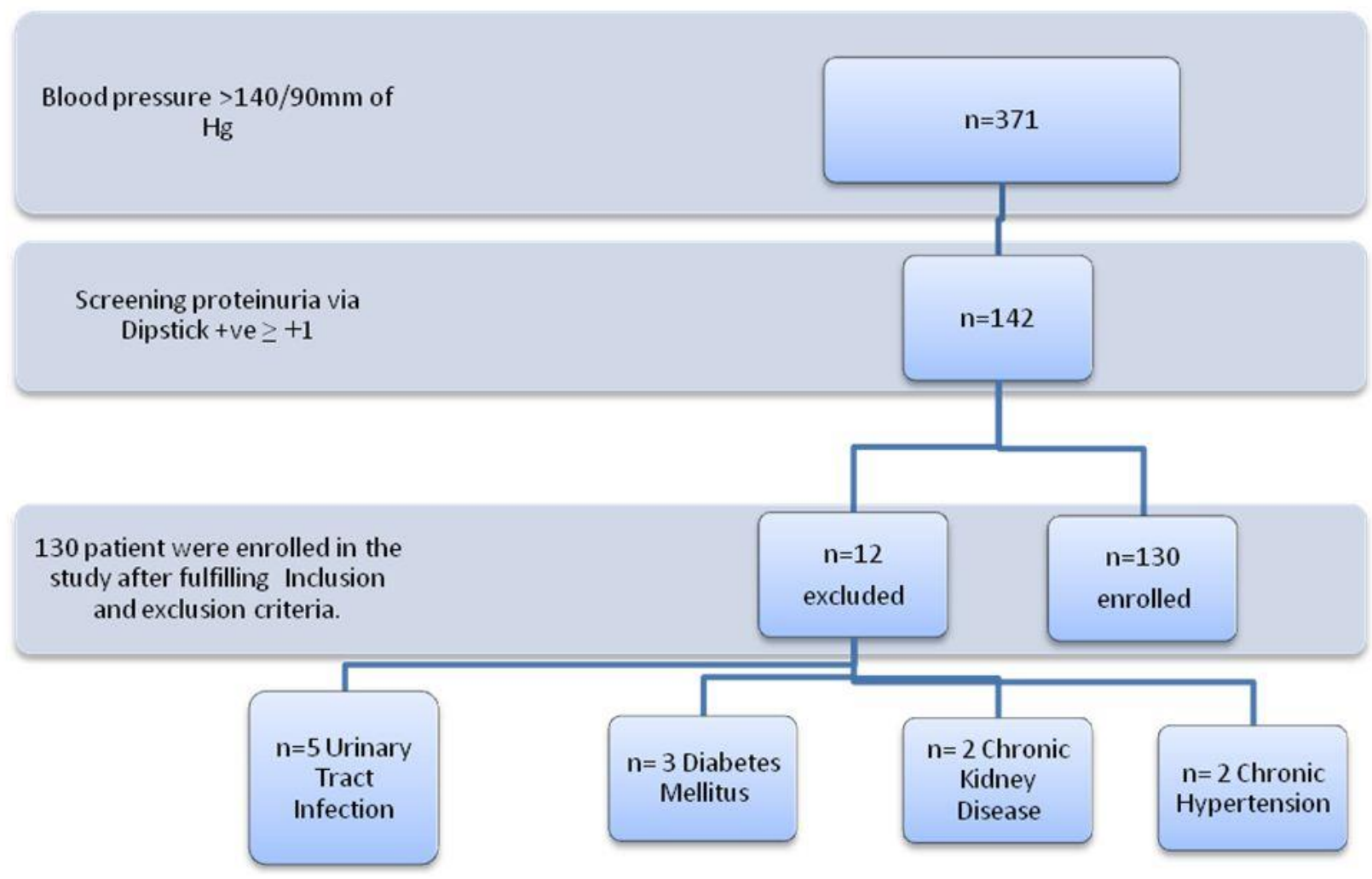

Figure 3: Flowchart showing selection of study size.

\section{Study variables}

1. Age

2. Parity

3. Gestational age

4. Body mass index

5. Random protein creatinine ratio

6. 24 hours protein creatinine ratio

\section{Duration of study}

- $\quad$ One year ( July 17 2018- June 16 2019)

\section{Screening for Proteinuria}

Patients admitted to the ward with blood pressure more than $140 \mathrm{~mm} \mathrm{Hg}$ systolic and $90 \mathrm{~mm} \mathrm{Hg}$ diastolic and bedside dipstick test was done in which paper strip is impregnated with indicator dye (bromocresol green) which changes colour in presence of protein. Sequential colour change occurs with increasing concentration. Protein by dipstick is graded as follows;
1. Negative $=0$
2. Trace $=10-20 \mathrm{mg} / \mathrm{dl}$
3. $+1=30 \mathrm{mg} / \mathrm{dl}$
4. $+2=100 \mathrm{mg} / \mathrm{dl}$
5. $+3=300 \mathrm{mg} / \mathrm{dl}$
6. $+4=1000-2000 \mathrm{mg} / \mathrm{dl}$

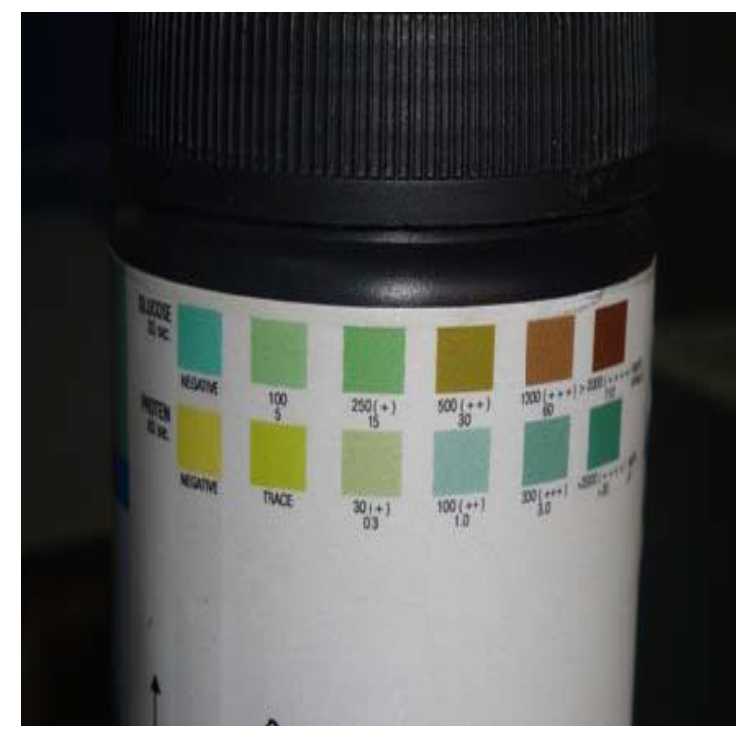

Figure 4: standard color grade of urinary protein in dipstick strip.

Patient with hypertension and proteinuria $\geq+1$ met the inclusion criteria were selected for the study. After a detailed explanation, a written informed consent was taken, and the patients were enrolled. Patient were evaluated by recording demographic profile, detailed history, general physical and systemic examination including obstetrics examination was done.

\section{Method of Blood Pressure Measurement}

Blood pressure of the patient was taken at Obstetrics and Gynaecology OPD and was repeated after admission after duration of 4 hours, measured on both arms, on sitting as well as after lying down in lateral position. 


\section{Urine Sample Collection Technique}

1. Urine test for estimation of $\mathrm{P} / \mathrm{C}$ ratio was done, patient asked to void urine and $3 \mathrm{ml}$ urine was collected clean, sterile plastic container for spot urine specimens.

2. For 24 hours urine collection patients are now advised and instructed to collect from second urine sample in a clean 5 litres container. The time of urine collection was recorded. Total urine is collected until next day till the recorded time.

3. Samples were sent to central biochemistry laboratory of same hospital. Assistance was taken from the laboratory technicians to prepare result where i) Total urinary protein was measured by a Pyrogallol Red Method. It was performed in automated biochemistry analyzer Mindray BS 360E Shenzhen.

ii) Urinary creatinine level was measured by modified Jaffee test (Photometry). It was performed in automated biochemistry analyzer Mindray BS 360 E Shenzhen.

4. Urine P/C Ratio was obtained by dividing the urinary protein concentration by urinary creatinine concentration.

5. Measurement of the 24 hours urine sample was performed on the same day as collection were completed.

Table 4: Normal values of protein excretion

\begin{tabular}{|c|c|c|}
\hline & $\begin{array}{c}\text { 24 hours urinary protein } \\
(\mathbf{m g} / \mathbf{2 4} \text { hours })\end{array}$ & \begin{tabular}{c} 
Protein/Creatinine ratio \\
\hline Negative
\end{tabular} \\
\hline Clinically significant proteinuria & $>300$ & $>0.3$ \\
\hline
\end{tabular}

\section{Statistical analysis}

Data analysis: Data was entered in microsoft excel and transferred to SPSS 16. Frequency distribution tables and necessary graphs were used for data interpretation. Pearson's correlation coefficient was used to calculate the relation between $\mathrm{P} / \mathrm{C}$ Ratio and 24 hour urine protein. Scattered diagram was used to show relation between $\mathrm{P} / \mathrm{C}$ Ratio and 24 hours urinary protein. ROC curve was used to identify the best cutoff of P/C Ratio to test accuracy of P/C ratio with 24 hours proteinuria. Sensitivity (true positive) and specificity (true negative), PPV, NPV and accuracy were calculated at the determined cutoff value of $\mathrm{P} / \mathrm{C}$ ratio. Difference was considered statically significant when the $p$ value was less than 0.05 .

\section{Ethical Consideration}

Ethical approval was obtained from Institutional Review Committee (IRC), National Medical College prior to my study on $16^{\text {th }}$ July 2018. After taking permission from the
Department, study was began from $17^{\text {th }}$ July 2018. Patients were explained about the purpose, risk and benefits, and protocol of the study in understandable language to the patients before enrolling. It was clearly informed that their data would be confidential, and they had the right to refuse the question or refuse participation at any time during the study. Fortunately, no one refused any question and participation. After explaining about the study and prior collecting the relevant information, informed written consent (in Nepali) was taken from the nearest relative with agreement of patient.

\section{RESULT}

This study used Urinary dipstick test $\geq+1$ for initial diagnosis of proteinuria in preeclampsia. The total sample size was 130 patients meeting the inclusion criteria (Hypertension and Proteinuria $\geq+1$ on urinary dipstick) were enrolled in the study . Then after enrollment patients were subjected to measure urine $\mathrm{P} / \mathrm{C}$ ratio and 24 hours urinary protein.

\section{Sociodemographic}

Table 5: Illustrating Descriptive statistics

\begin{tabular}{|c|c|c|c|c|}
\hline & Minimum & Maximum & Mean & Std. Deviation \\
\hline Age & 18 YEARS & 37 YEARS & 25.2 & 3.9 \\
\hline BMI & $18.5 \mathrm{KG} / \mathrm{M}^{2}$ & $30.3 \mathrm{KG} / \mathrm{M}^{2}$ & 23.4 & 2.8 \\
\hline Urinary P/C ratio & 0.07 & 2.1 & 0.6 & 0.4 \\
\hline 24HRS URINE PROTEIN & $136 \mathrm{MG} / 24 \mathrm{HRS}$ & $2876 \mathrm{MG} / 24 \mathrm{HRS}$ & 690.5 & 531.8 \\
\hline
\end{tabular}

Age: The minimum age of the patient was 18 years and maximum age was 37 years with mean age of 25.2 years (SD \pm 3.9 )

BMI: The minimum BMI of a patient was 18.5 and maximum was $30.3 \mathrm{Kg} / \mathrm{m}^{2}$. Mean BMI was 23.4 (SD \pm 2.84 ) 
24 Hours Urine Protein: Minimum was $136 \mathrm{mg} / 24$ hours and maximum was $2876 \mathrm{mg} / 24$ hours. Mean was 690.5 (SD \pm 531.8 ). Out of which 105 patient had proteinuria $>300 \mathrm{mg} / 24$ hours and 25 patient had proteinuria $<300 \mathrm{mg} / 24$ hours. Though 25 patient had 24 hour urinary protein $<300 \mathrm{mg}$ but these patient met the inclusion criteria of hypertension and urinary dipstick proteinuria of $\geq+1$.
Urinary $\mathrm{P} / \mathrm{C}$ ratio: The minimum urinary $\mathrm{P} / \mathrm{C}$ ratio was 0.07 and maximum was 2.1. Mean was $0.6(\mathrm{SD} \pm 2.8)$. 130 patient who were selected for the study all fullfilled and met the inclusion criteria (Hypertension and proteinuria $\geq+1$ ) and then were subjected to check urinary $\mathrm{P} / \mathrm{C}$ ratio which showed variable range of ratio.

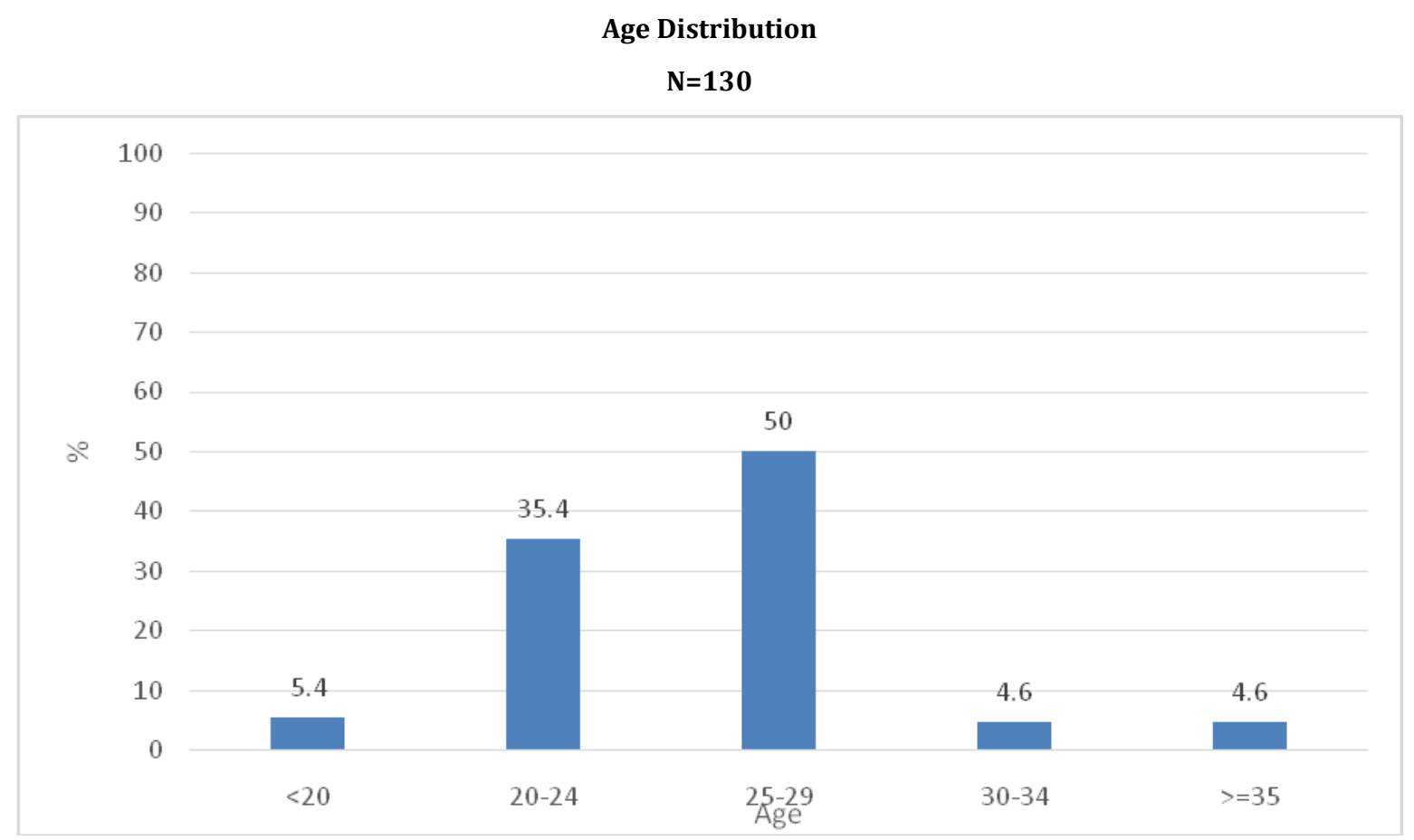

Figure 5: Distribution of patient of preeclampsia by age group

The minimum age of the patient was 18 years and maximum age was 37 years with mean age of 25.2 years (SD \pm 3.9 ). Figure 5 shows distribution of patients by age group majority $65(50 \%)$ were between $25-29$ years, 46 (35.4\%) were between $20-24$ years age group, 7(5.4\%) were $<20$ years, remaining $6(4.6 \%)$ were of age group $30-34$ years and $>$ 35years.

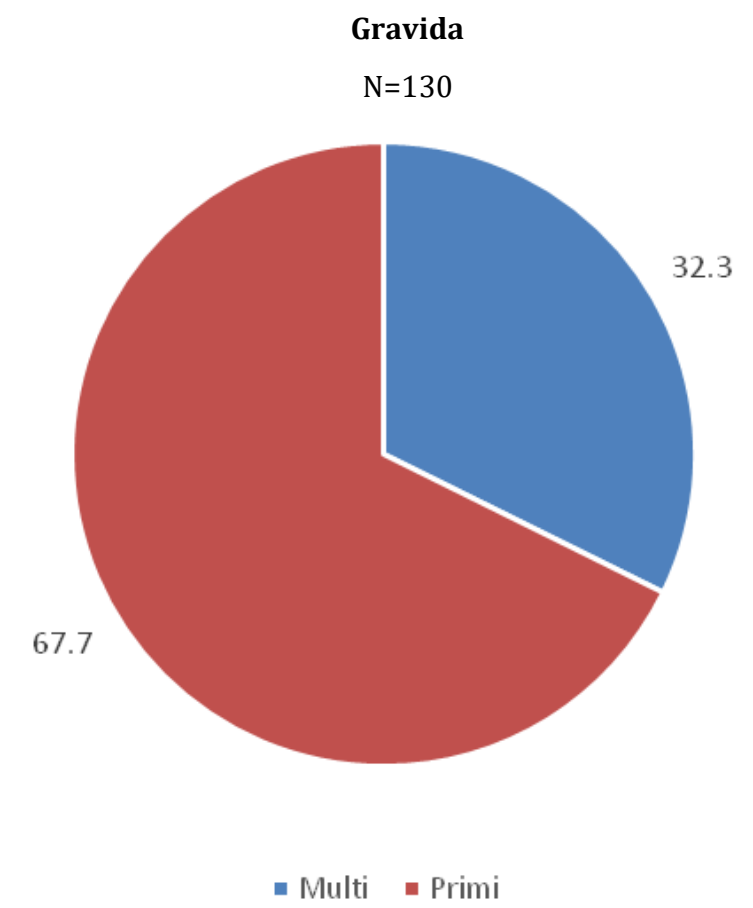

Figure 6: Distribution of patient with preeclampsia according to gravida.

Around two third $(88,67.7 \%)$ of total sample were primigravida whereas remaining $(42,32.3 \%)$ were multigravida. 
Body Mass Index (BMI)

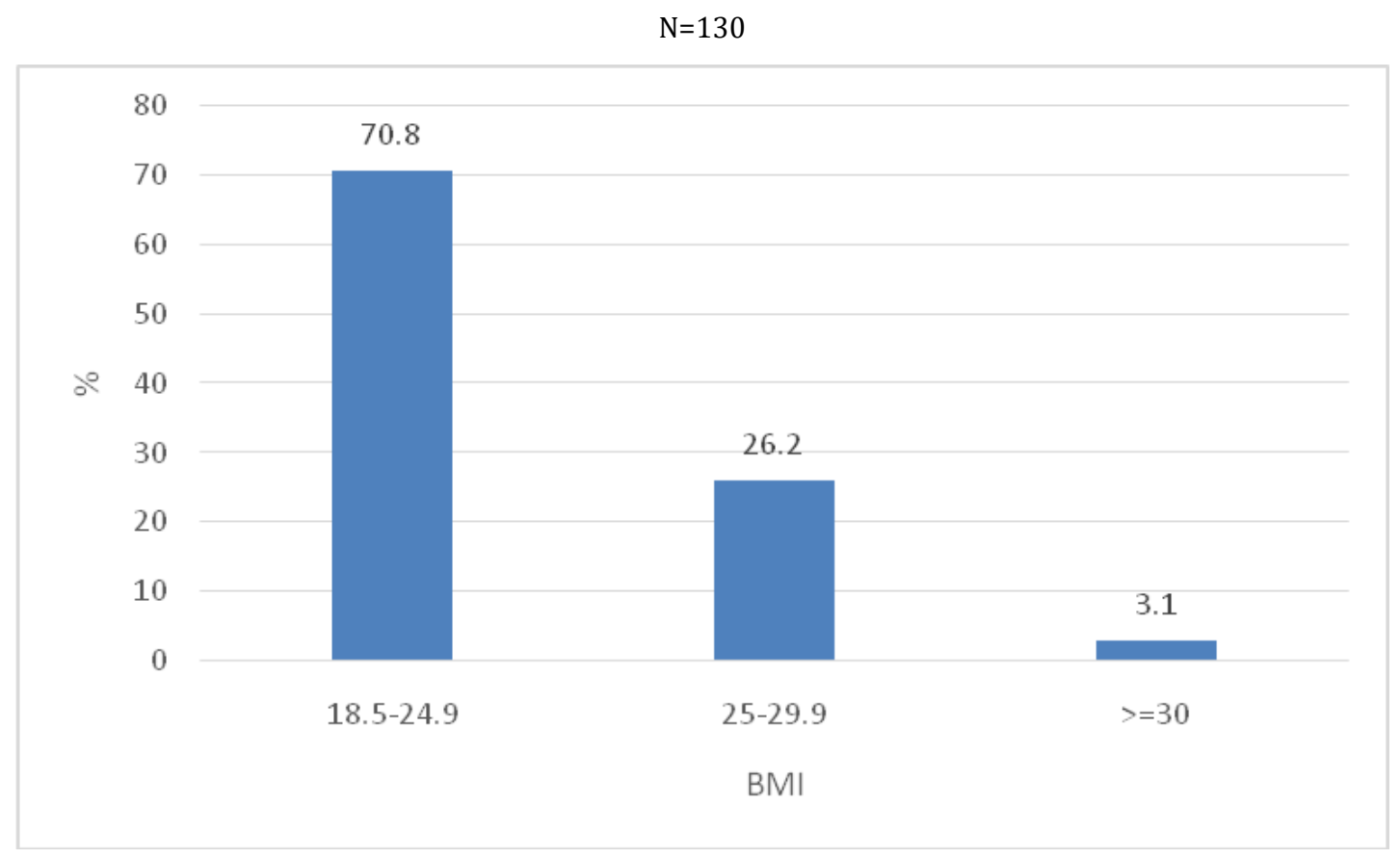

Figure 7: Distribution of patient with preeclampsia according to BMI

Range of BMI is 18.5 to $30.3 \mathrm{Kg} / \mathrm{m}^{2}$. Mean BMI was 23.4 (SD \pm 2.84 ). Majority (92, 70.8\%) lies between $18.5-24.9 \mathrm{Kg} / \mathrm{m}^{2}$ followed by 25 to $29.9 \mathrm{Kg} / \mathrm{m}^{2}(34,26.2 \%)$ and above $30 \mathrm{Kg} / \mathrm{m}^{2}$ were $(4,3.1 \%)$.

\section{Urine protein creatinine $(p / c)$ ratio}

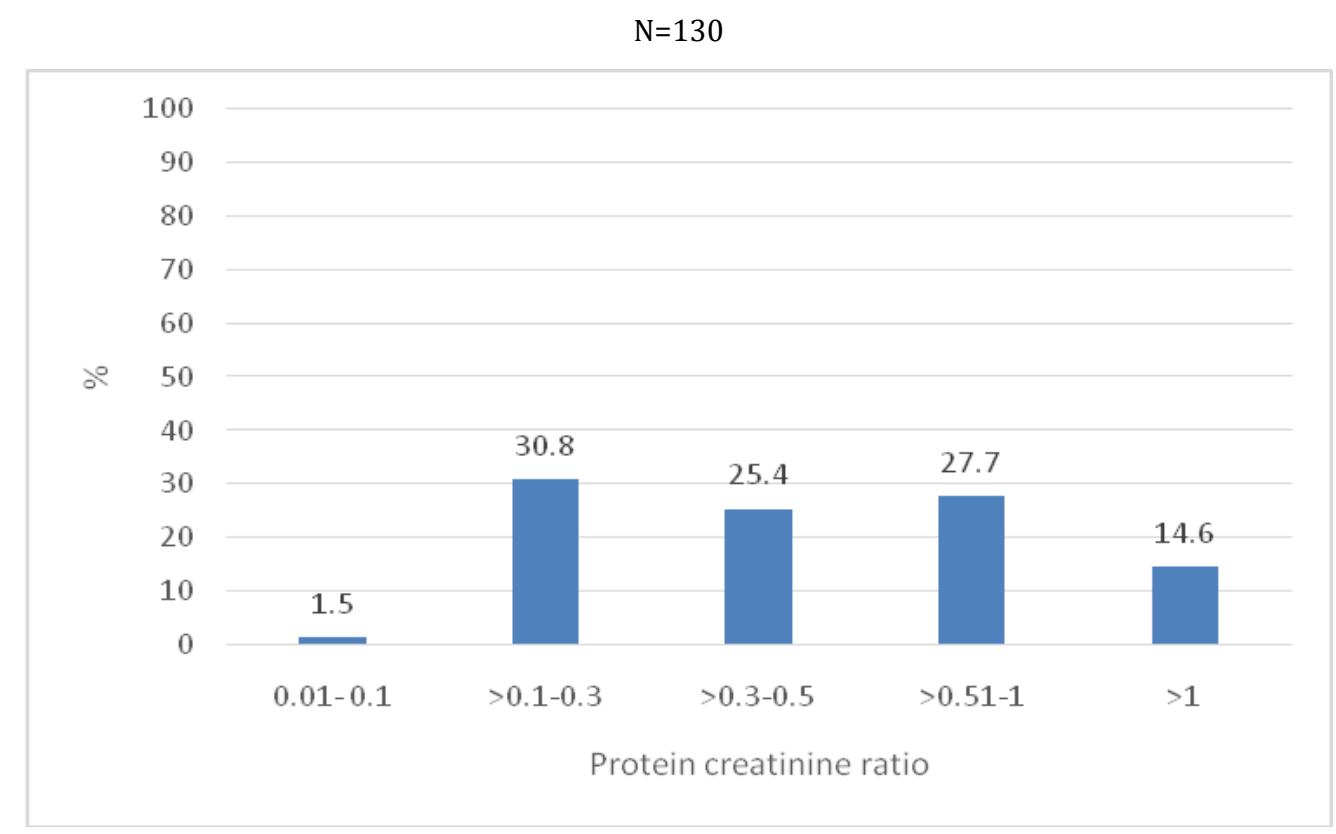

Figure 8: Distribution of patient with preeclampsia according to $\mathrm{P} / \mathrm{C}$ Ratio

Among 130 participants, range was 0.07 to 2.1 with the average of $0.6(\mathrm{SD} \pm 0.4)$. Spot $\mathrm{P} / \mathrm{C}$ ratios were categorized into five groups, where majority $40(30.8 \%)$ lies in between 0.1-0.3, followed by $>0.51$ to 1 (36 27.7\%), followed by $33(25.4 \%)$ between 0.31 to 0.5 and remaining $19(14.6 \%)$ were $>1$. Among five groups, lowest was between 0.01-0.1 $2(1.5 \%)$. All 130 patients met the inclusion criteria of hypertension and urinary dipstick proteinuria of $\geq+1$ therefore were included in studies. 
24 hours urine Protein

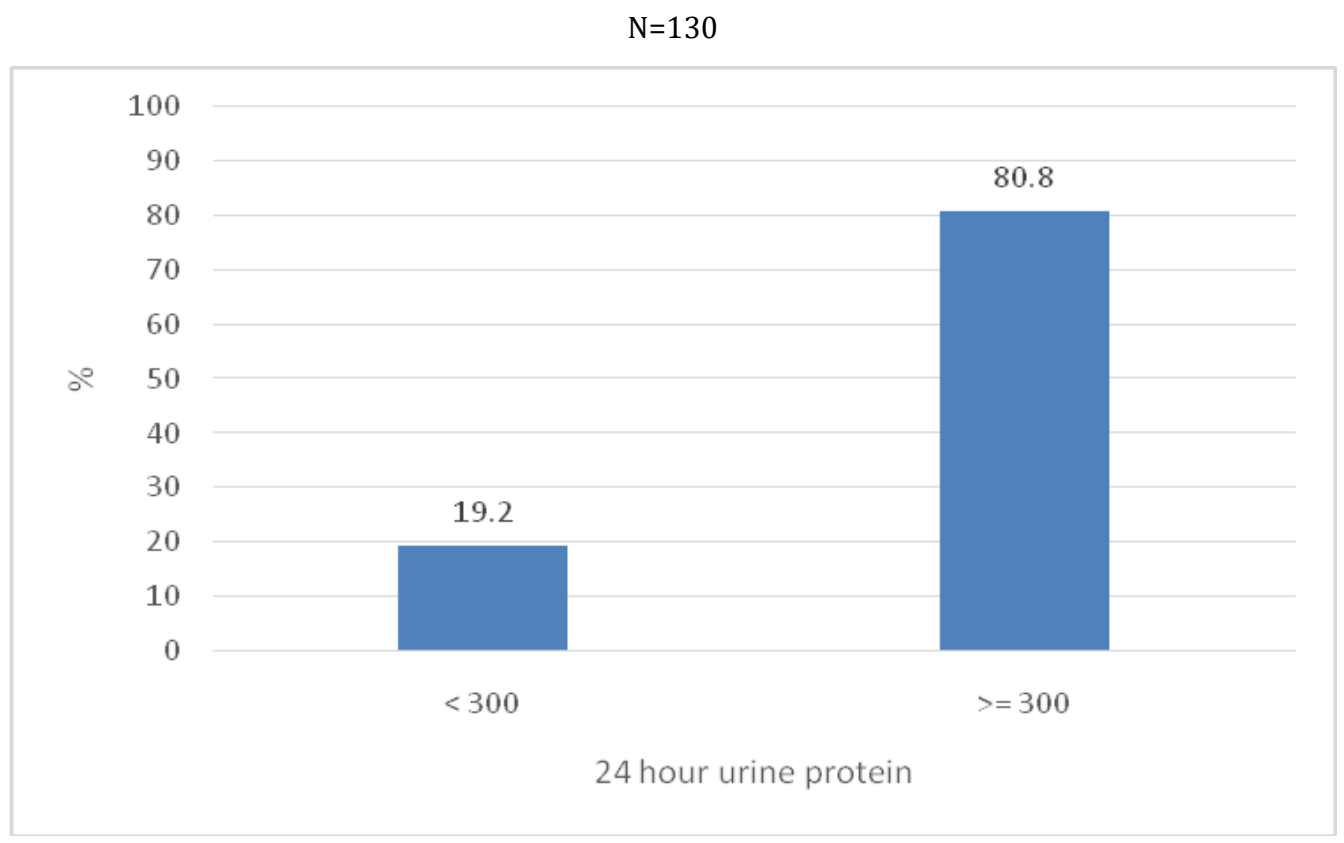

Figure 9: Distribution on the basis of 24 hours urine protein level

From our study, range of proteinuria among participants was 136 to $2876 \mathrm{mg}$ per 24 hours with average of $690.5 \mathrm{mg}$ per 24 hours with . From our study, majority of 105 (80.8\%) had proteinuria more than or equal to $300 \mathrm{mg}$ per 24 hours and remaining $25(19.2 \%)$ were $<300 \mathrm{mg}$ per 24 hours. Though 25 patient had 24 hour urinary protein $<300 \mathrm{mg}$ but these patient met the inclusion criteria of hypertension and urinary dipstick proteinuria of $\geq+1$.

Intrauterine growth retardation (IUGR)

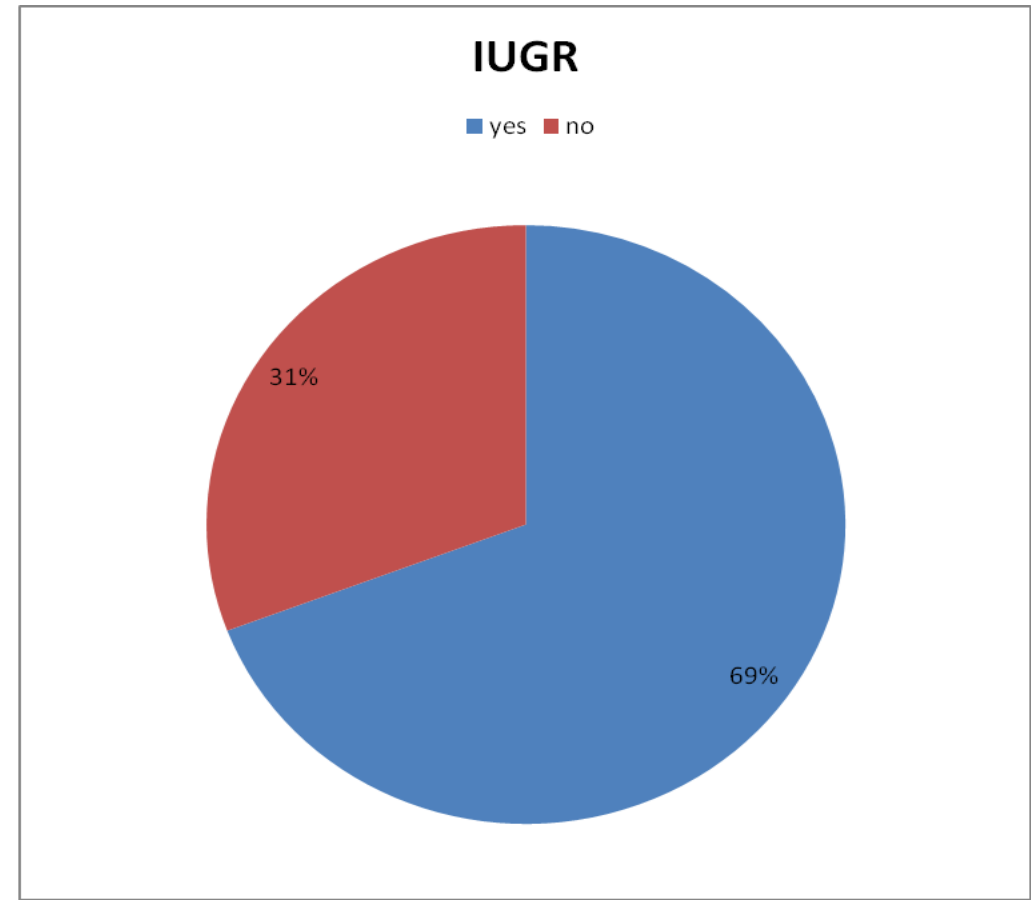

Figure 10: Distribution on the basis of IUGR

Out of 130 participants, 90 (69\%) had IUGR and 40(31\%) no IUGR. 
Correlation between protein creatinine ratio and 24 hours urine protein

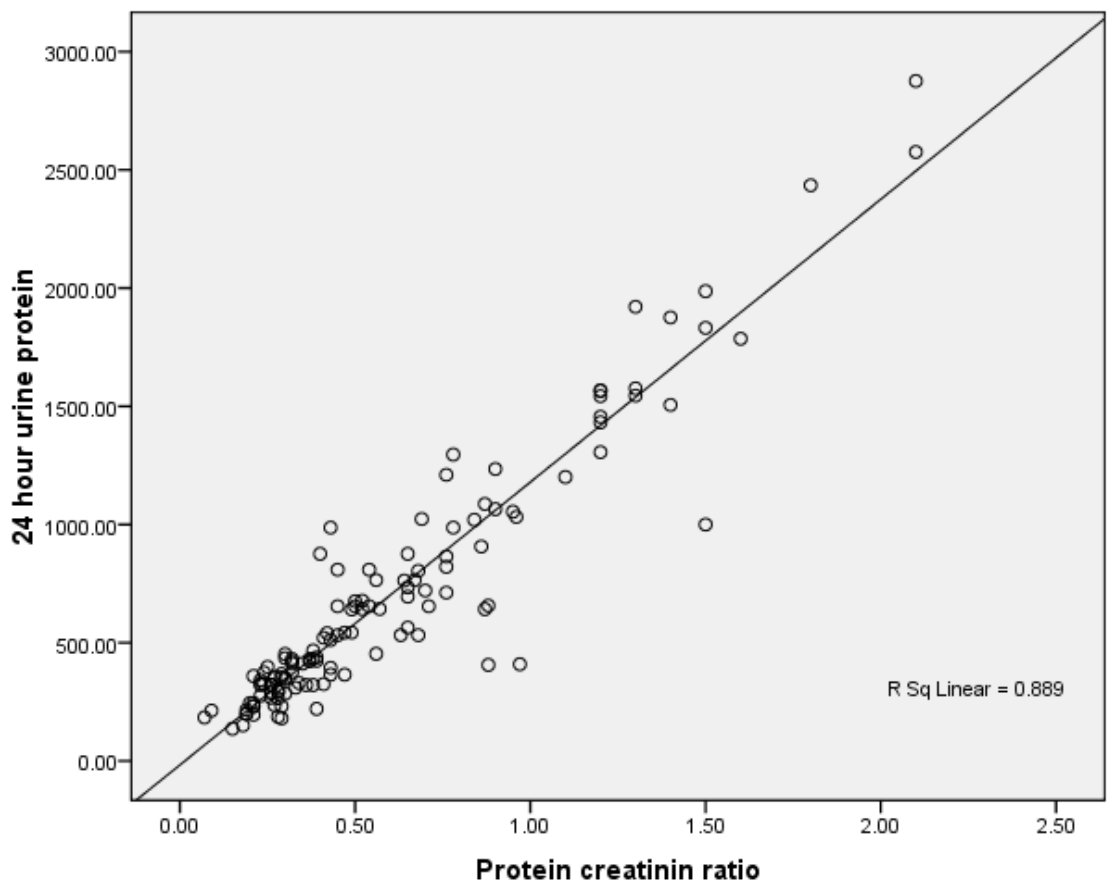

Figure 11: Positive correlation with between protein creatinine ratio and 24 hours urine protein.

Table 6: Pearson correlation coefficient between protein creatinine ratio and 24 hours urine protein with $P$ value

\begin{tabular}{|c|c|}
\hline Pearson Correlation (r) & 0.943 \\
\hline P value & $<0.001$ \\
\hline
\end{tabular}

It shows that there is significant positive relationship between 24 hours urine protein and urine protein creatinine ratio. As Pearson Correlation ( $\mathrm{r}$ ) $=0.943$ which represents that there is a strong positive correlation between two variables since the result is closer to +1 . $P$ value being $<0.001$ represent that the variables are statically significant.

Table 7: Two by two table between spot protein creatinine ratio and 24 hours urine protein

\begin{tabular}{|c|c|c|c|c|}
\hline \multicolumn{5}{|c|}{24 hours protein urine } \\
\hline \multirow{4}{*}{ 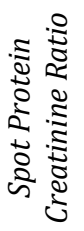 } & & $>=300$ & $<300$ & Total \\
\hline & $>=0.31$ & 87(True Positive) & 1(False Positive) & 88 \\
\hline & $<0.31$ & 18(False Negative) & 24 (True Negative) & 42 \\
\hline & Total & 105 & 25 & 130 \\
\hline
\end{tabular}

Here, spot P/C ratio was analyzed considering 24 hours protein urine as gold standard test. From the table,

sensitivity $=\frac{\text { True Positive }}{\text { True positive +False Negative }}=\frac{87}{(87+18)} \times 100 \%=82.85 \%$,

specificity $=\frac{\text { True Negative }}{\text { True Negative }+ \text { False Positive }}=\frac{24}{(24+1)} \times 100 \%=96 \%$,

positive predictive value $=\frac{\text { True positive }}{\text { True positive }+ \text { False Positive }}=\frac{87}{(87+1)} \times 100 \%=98.86 \%$

negative predictive value $=\frac{\text { True negative }}{\text { false negative }+ \text { true negative }}=\frac{24}{18+24} \times 100 \%=57.14 \%$.

Accuracy $=\frac{\text { True Positive }+ \text { True Negative }}{\text { True positive }+ \text { False Negative }+ \text { false positive }+ \text { true negative }}=\frac{87+24}{(87+18+1+24)} \times 100 \%=85.38 \%$ 


\section{ROC analysis}

Table 8: Test variable result of Protein creatinine ratio with area under the curve, prevalence, cutoff of PCR along with sensitivity, specificity ,PPV,NPV and accuracy

\begin{tabular}{|c|c|c|c|c|c|c|c|c|c|c|}
\hline \multirow{2}{*}{ 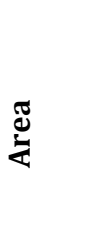 } & \multirow{2}{*}{  } & \multirow{2}{*}{2} & \multicolumn{2}{|c|}{$\begin{array}{l}\text { 95\% Confidence } \\
\text { Interval }\end{array}$} & \multirow{2}{*}{$\stackrel{\mathscr{0}}{\stackrel{0}{0}}$} & \multirow{2}{*}{ 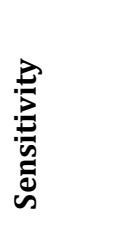 } & \multirow{2}{*}{ 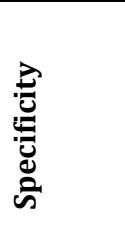 } & \multirow{2}{*}{$\vec{a}$} & \multirow{2}{*}{$\vec{z}$} & \multirow{2}{*}{ 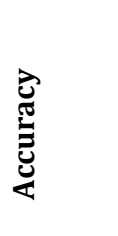 } \\
\hline & & & ${ }_{0}^{0}$ & ఏ̄ & & & & & & \\
\hline 0.938 & 0.021 & $<0.001$ & 0.897 & 0.979 & 0.31 & 82.9 & 96 & 98.9 & 57.1 & 85.4 \\
\hline
\end{tabular}

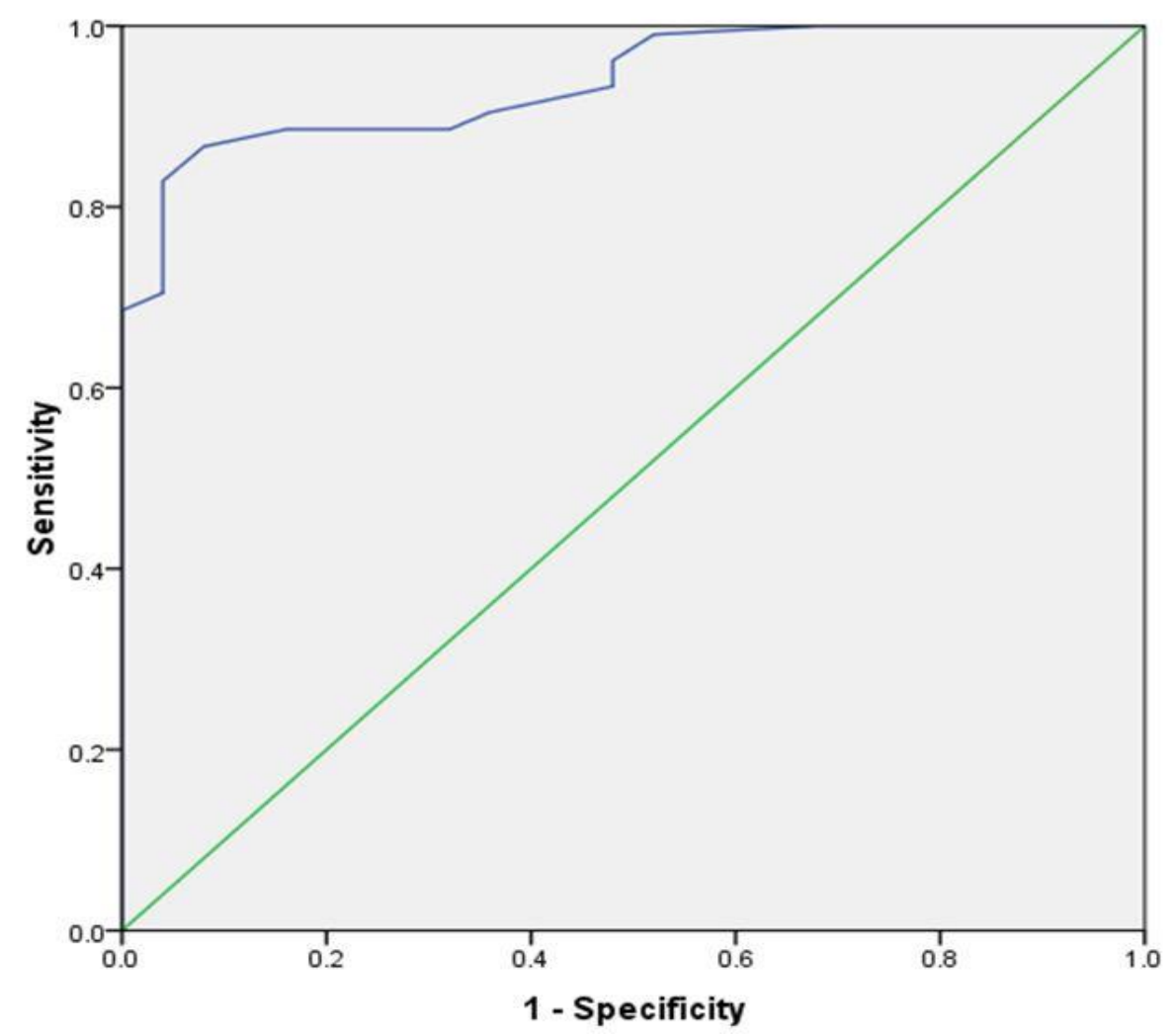

Figure 12: Receiver operating characteristic curve showing diagnostic ability of spot $\mathrm{P} / \mathrm{C}$ ratio.

Test was also triangulated from ROC curve and result of Area Under Curve (AUC) . In the ROC curve as shown in graph, Y axis represents sensitivity which represents the true positive result and also called true positive rate whereas, $\mathrm{X}$ axis represents 1 - specificity which represents the false positive result and also called false positive rate. SPSS gave curve against the axis. Curve nearer to upper left corner shows sensitivity and specificity. From the graph, curve pointed to upper left corner gave same findings given in two by two table above. From the graph and table AUC was 0.938 which is closer to maximum (1) with the level of significance $<0.001$. Our cut off value was 0.31

From the two by two table proportion correctly classified (accuracy) was found to be $85.4 \%$.

\section{DISCUSSION}

One of the most common problems faced by pregnant women. Preeclampsia is the major cause of maternal mortality and morbidity. Measurement of blood pressure and significant amount of proteinuria are the important criteria for preeclampsia. Measuring 24 hours urinary protein is considered as the gold standard and definitive method to quantify the proteinuria. However it is considered time consuming and troublesome, waiting for result of 24 hours urinary protein collection leads to delay diagnosis of pre eclampsia. Quantifying the proteinuria via simple and reliable test is required. Though urinary Dipstick for protein is simple bedside method, it has been criticized because it is a poor predictor for significant proteinuria for diagnosis of pre eclampsia. For quantitative analysis of proteinuria protein creatinine ratio is considered good and correlates well with 24 hours urinary protein.

This study was done to find the correlation between protein creatinine ratio and 24 hours proteinuria and find the accuracy of the test among the pregnant mother with preeclampsia.

\section{Age}

This study shows that the age group of the patients ranged from 18 to 37 years. The majority 50\% come under the age group of 25-29 years. The mean age is 25.2 years with $(S D \pm 3.9)$. Finding were similar to that of Durnwald ${ }^{30}$ with mean age of 26.1 years, Kumari et al with mean age 24.3 
years . Contrast to this study none of the cases were more than 40 , who could have both higher risk of preeclampsia and complication to maternal and fetus. .50

\section{Parity/Gravida}

This study found that preeclampsia was more common among primigravida. It was more than two third of the total sample. Other studies also identified same results. A systematic review illustrates same findings done by Duckitt and Harrington, which mentioned that primigravida is more at risk of preeclampsia than multigravida by 2.91 folds (Range 1.28 to 6.61).22 This may be explained by hypothesis by immunogenicity to maternal first exposure to chorionic villi of fetal origin. Bdolah Y el al also stated that nulliparous women have an increased risk of developing preeclampsia with hypothesis of relatively higher circulating anti angiogenic levels with higher levels of circulating sFlt1 in nullipara. ${ }^{23}$

But in contrast to that, a systemic review and meta-analysis done in Ethiopia by Berhe et al. pointed out a fact that there is no association between gravida and hypertension in pregnancy with odds ratio of 1.37 .22 .

\section{BMI}

In present study, mean BMI was 23.4 (SD \pm 2.84$)$, majority $(70.8 \%)$ of patient lies between $18.5-24.9 \mathrm{~kg} / \mathrm{m}^{2}$ which is categorized as normal, overweight lies between 25-29.9 were $26.2 \%$ and remaining $3.1 \%$ were class I obese according to WHO classification. Contrast to present study findings Systemic analysis and meta-analysis done by Duckitt et al. showed that with BMI $25 \mathrm{Kg} / \mathrm{m}^{2}$ before pregnancy can results in preeclampsia with the odds ratio $2.47 . .^{22}$ Similarly Ramos et al also showed BMI $\geq 25.8$ has relative risk of 2.32.7. ${ }^{21}$ However, this study has collected BMI at pregnancy and limits the clear evidence.

\section{IUGR}

Out of 130 patients, 90 (69\%) had IUGR and 40 (31\%) has no IUGR. Similar to this study, study conducted by Weiler et al shows preeclamptic women who delivered growth restricted child were $79 \%$ diagnosed IUGR antenatally and remaining $11 \%$ were not growth restricted.(p,0.0001). ${ }^{26}$ Studies have showed that higher the proteinuria higher the chances of high maternal and fetal complication.

In contrast to that, Melese et al. differentiated outcomes as favorable $(53.5 \%)$ and non-favorable $(45.5 \%)$, then enlisted out the unfavorable outcomes out of which stillbirth accounted $22 \%$, low birth weight $13 \%$, low apgar score $10.8 \%$, low birth weight $10.8 \%$, birth asphyxia $10.1 \%$, abortions $8.9 \%$, IUGR $4.4 \% .25$

There are high chances of IUGR with pre-eclampsia, in which obstetrics clinician must be watchful regarding growth retardation when patient with pre-eclampsia comes. ${ }^{27}$ More delay in collecting urinary protein would take mother and child at risk zone.

\section{Correlation and accuracy of diagnostic test with 24 hours urine protein}

This study showed linear positive relationship between protein creatinine ratio and 24 hours urine protein with the Pearson's correlation coefficient $r$ (130) was 0.943. This shows there is strong positive correlation between protein creatinine ratio and 24 hours urine protein since the result is closer to 1.

ROC curve analysis was done mainly to evaluate the accuracy of the test and this study revealed $\mathrm{P} / \mathrm{C}$ ratio had sensitivity of $82.86 \%$, specificity $96 \%$, positive predictive value $98.9 \%$ and negative predictive value $57.1 \%$ with the accuracy of $85.4 \%$. It also gave the cutoff point of $\mathrm{P} / \mathrm{C}$ ratio as 0.31 along with AUC 0.938 which is closer to 1 represents excellent data analysis.

Similar to this study, Kucukgoz et al studied patient in 3 groups for gestational hypertension, preeclampsia and severe preeclampsia for $\mathrm{P} / \mathrm{C}$ ratio and 24 hours urine protein. In patients with pre eclampsia gave the correlation coefficients $(\mathrm{r})=0.814$ with $\mathrm{p}$ value $<0.001$ which concludes the good correlation between $\mathrm{P} / \mathrm{C}$ ratio and 24 hours urine protein. ${ }^{34}$

Another study, Valdes et al. , conducted, a study in preeclampsia which shows significant correlation with $r=0.6$ $(\mathrm{p}<0.001)$ between two variables $(24$ hours urine protein and protein creatinine ratio). In the same study, best $\mathrm{P} / \mathrm{C}$ ratio was 0.36 for the diagnosis of pre-eclampsia with PPV 96.4\% and AUC 0.8802.28

Similar to this study, a study conducted by Shahbazian and Hosseini conducted a study in 81 patients with preeclampsia to determine proteinuria in comparison with spot $\mathrm{P} / \mathrm{C}$ ratio and 24 hours urinary protein. Study shows a strong correlation between spot $\mathrm{P} / \mathrm{C}$ ratio and 24 hours urinary protein with Pearson coefficient $(r)=0.84(\mathrm{P}<0.001)$. The cutoff point for spot $\mathrm{P} / \mathrm{C}$ ratio at 0.20 . The sensitivity, specificity , PPV, NPV were 91.2\%, 87.8\%, 94.4\% and 96.8\% respectively. ${ }^{31}$

Similarly, for same tests, Robert et al., showed strong correlation ( $\mathrm{r}=0.94)$ with sensitivity, specificity, PPV and NPV of $93 \%, 90 \%, 87$ and $95 \%$ respectively at $>300 \mathrm{mg}$ proteinuria. But for $>5000 \mathrm{mg}$ proteinuria, it showed $100 \%$, 99\%, 75\% and 99\% respectively (Robert et al). It showed with high proteinuria, $\mathrm{P} / \mathrm{C}$ ratio test would be more accurate. These findings were similar to our study. ${ }^{29}$

Study done by Demirci et al. ${ }^{33}$, found good 0.758 correlation coefficient (r) between the two variables and find 0.97 AUC with 91\% sensitivity, 95.4\% specificity, 95.2\% PPV and 91.2\% NPV whereas, Hossain et al., showed $r=0.81$ with $\mathrm{P}$ $<0.000$ and $82 \%$ sensitivity and $79 \%$ specificity with cut-off value at 0.14 for $300 \mathrm{mg}$ per 24 hours. $^{32}$

In contrast to these studies, studies done by Durnwal and Mercer, Soni et al., Kayatas et al., and Montero et al., concluded that $\mathrm{P} / \mathrm{C}$ ratio is not a perfect diagnostic test for pre-eclampsia. All of them showed poor correlation between two tests. They showed poor PPV, NPV, sensitivity and specificity with different protein levels. Durnwal and Mercer showed $r^{2}=0.41$ with positive predictive value of $85.5 \%$ and negative predictive value of only $47.5 \%$ with sensitivity $81 \% .35$ Aggarwal et al., showed NPV of only $29.2 \%$ with sensitivity $72 \%$ and specificity $75 \% .{ }^{26}$ Similarly, Kayatas et al. showed $60 \%$ sensitivity $60 \%, 78 \%$ specificity, $78 \%$ PPV and $61 \%$ NPV. ${ }^{27}$ Moreover, Montero et al., found poor correlation with $<300 \mathrm{mg}(\mathrm{r}=0.498){ }^{28}$ 
Table 9: Comparison between this studies with other studies

\begin{tabular}{|l|l|l|}
\hline Studies & Correlation coefficient ( $\mathbf{r}$ ) & P-value \\
\hline Kucukgoz et al (2017) & 0.814 & $<0.001$ \\
\hline Valdes et al (2016) & 0.6 & $<0.001$ \\
\hline Demirci et al (2015) & 0.758 & $<0.001$ \\
\hline Shahbazian and Hosseini (2008) & 0.84 & $<0.001$ \\
\hline Robert et al(1997) & 0.94 & $<0.001$ \\
\hline This study & 0.943 & $<0.001$ \\
\hline
\end{tabular}

Multiple studies on same topic done around the globe have shown chances of both high and low accuracy of the tests. Majority of the studies have stressed on spot urine P/C ratio's capacity of predicting correctly as done by 24 hours urinary protein test.

This study showed positive correlation $(r=0.943)$ between spot protein creatinine ratio and 24 hours urine protein, with $82.9 \%$ sensitivity and $96 \%$ specificity. Hence, this test can be used during emergency condition to save life of mother and child with instant test and prompt decision. Pregnant women with suspected preeclampsia can be assessed by taking spot protein creatinine ratio to save life. For the true positive, test would show nearly correct result. But for negative cases, there are chances of incorrect diagnosis by the test.

\section{CONCLUSION}

This study showed protein creatinine ratio is as capable as 24 hours protein urine to diagnose pregnant mother with preeclampsia. Spot $\mathrm{P} / \mathrm{C}$ ratio provides effortless result with high validity and reliability.

\section{RECOMMENDATION}

Apart from this study, various studies have recommended to use protein creatinine ratio as an alternative for 24 hours urine protein in an emergency. This test may not be considered gold standard as sample size may not be representative and study design was cross-sectional. So, present study further recommends conducting randomized control trial (RCT) in the settings like rural Nepal, so that it can get strong results and implement it efficiently.

\section{REFERENCES}

1. Cunningham FG, Leveno KJ, Bloom SL, Hath JC,Gilstrap L, Wenstrom KD editors. Williams Obstetrics. 24th ed. Mc GrawHill.In: Hypertensive Disorders in Pregnancy. 2010:728-730

2. Steegers EA, Von Dadelszen P, Duvekot JJ, Pijnenborg R. Preeclampsia. The Lancet. 2010 Aug 21; 376(9741):631-44. https://doi.org/10.1016/S0140-6736(10)60279-6

3. Say L, Chou D, Gemmill A, Tunçalp Ö, Moller AB, Daniels J, Gülmezoglu AM, Temmerman M, Alkema L. Global causes of maternal death: a WHO systematic analysis. The Lancet Global Health. 2014 Jun 1; 2(6):e323-33. https://doi.org/10.1016/S2214-109X(14)70227-X

4. Pasha O, McClure EM, Saleem S, Tikmani SS, Lokangaka A, Tshefu A, Bose CL, Bauserman M, Mwenechanya M, Chomba E, Carlo WA. A prospective cause of death classification system for maternal deaths in low and middle-income countries: results from the Global Network Maternal Newborn Health Registry. BJOG: An International Journal of Obstetrics \& Gynaecology. 2018 Aug; 125(9):1137-43. https://doi.org/10.1111/14710528.15011

5. Pant PD, Suvedi BK, Pradhan A, Hulton L, Matthews Z. Improvements in maternal health in Nepal: Further analysis of the 2006 Nepal Demographic and Health Survey.
6. Sibai BM. Preeclampsia as a cause of preterm and late preterm (near-term) births. InSeminars in perinatology 2006; 30(1):1619). WB Saunders.

https://doi.org/10.1053/j.semperi.2006.01.008

7. Jansen MA, Pluymen LP, Dalmeijer GW, Groenhof TK, Uiterwaal CS, Smit HA, van Rossem L. Hypertensive disorders of pregnancy and cardiometabolic outcomes in childhood: A systematic review. European journal of preventive cardiology. 2019 May $27 ; 2047487319852716$. https://doi.org/10.1177/2047487319852716

8. El-Sayed AA. Preeclampsia: A review of the pathogenesis and possible management strategies based on its pathophysiological derangements. Taiwanese Journal of Obstetrics and Gynecology. 2017 Oct $1 ;$ 56(5):593-8. https://doi.org/10.1016/j.tjog.2017.08.004

9. Jeyabalan A, Conrad KP. Renal function during normal pregnancy and preeclampsia. Front Biosci. 2007 Jan 1; 12(1):2425-37. https://doi.org/10.2741/2244

10. Montero N, Montero N, Soler MJ, Soler MJ, Pascual MJ, Pascual MJ, Barrios C, Márquez E, Rodríguez E, Berrada A, Riera M. Correlation between the protein/creatinine ratio in spot urine and 24-hour urine protein. Nefrología (English Edition). 2012 Jul 1; 32(4):494-501.

11. Rodriguez-Thompson D, Lieberman ES. Use of a random urinary protein-to-creatinine ratio for the diagnosis of significant proteinuria during pregnancy. American journal of obstetrics and gynecology. 2001 Oct $1 ; 185(4): 808-11$. https://doi.org/10.1067/mob.2001.117349

12. Al RA, Baykal C, Karacay O, Geyik PO, Altun S, Dolen I. Random urine protein-creatinine ratio to predict proteinuria in newonset mild hypertension in late pregnancy. Obstetrics \& Gynecology. 2004 Aug 1; 104(2):367-71. https://doi.org/10.1097/01.AOG.0000134788.01016.2a

13. GangaramR, OjwangPJ, MoodleyJ, MaharajD. Accuracy of urine dipstick as a screening test for proteinuria in hypertensive disorders of pregnancy. Hypertension in pregnancy. 2005; 24:117-23 https://doi.org/10.1081/PRG-200059849

14. Sultana MN, Majumder B, Rahman MJ, Moniruzzaman AM, Suja AM, Ali ME, et al. Dipstick Method versus Spot Urinary Protein Creatinine Ratio for Evaluation of Massive Proteinuria in Childhood Nephrotic Syndrome. Mymensingh Med J MMJ. 2018 Apr; 27(2):369-74.

15. Shah S, Sulthana P. A Comparative Study of Urine Dipstick and Urine Protein Creatinine Ratio with 24 Hour Urinary Protein in Estimation of Significant Proteinuria in Pre-Eclampsia. IOSR Journal of Dental and Medical Sciences (IOSR-JDMS) e-ISSN: 2279-0853, p-ISSN: 2279-0861. 2019; 18(7):21-29

16. Wheeler TL, Blackhurst DW, Dellinger EH, Ramsey PS. Usage of spot urine protein to creatinine ratios in the evaluation of preeclampsia. Am J Obstet Gynecol. 2007 May 1; 196(5):465.e1465.e4. https://doi.org/10.1016/j.ajog.2006.10.892

17. Ginsberg JM, Chang BS, Matarese RA, Garella S. Use of single voided urine samples to estimate quantitative proteinuria. New England Journal of Medicine. 1983 Dec 22; 309(25):1543-6. https://doi.org/10.1056/NEJM198312223092503

18. Jan, S., Javaid, C., \& Firdous, N. Diagnostic accuracy of spot urinary protein/creatinine ratio for proteinurea in pregnancy induced hypertension. International Journal of Reproduction, Contraception, Obstetrics and Gynecology. 2017 May, 6(5):2083. https://doi.org/10.18203/2320-1770.ijrcog20171981

19. Neithardt AB, Dooley SL, Borensztajn J. Prediction of 24-hour protein excretion in pregnancy with a single voided urine 
protein-to-creatinine ratio. American journal of obstetrics and gynecology. 2002 May 1; 186(5):883-6. https://doi.org/10.1067/mob.2002.123055

20. Bianco A, Stone J, Lynch L, Lapinski R, Berkowitz G, Berkowitz RL. Pregnancy outcome at age 40 and older. Obstet Gynecol. 1996 Jun; 87(6):917-22. https://doi.org/10.1016/00297844(96)00045-2

21. Ramos JG, Sass N, Costa SH. Preeclampsia. Revista Brasileira de Ginecologia e Obstetrícia/RBGO Gynecology and Obstetrics. 2017 Sep; 39(09):496-512. https://doi.org/10.1055/s-00371604471

22. Duckitt K, Harrington D. Risk factors for pre-eclampsia at antenatal booking: systematic review of controlled studies. BMJ. 2005 Mar 12; 330(7491):565. https://doi.org/10.1136/bmj.38380.674340.E0

23. Bdolah Y, Elchalal U, Natanson-Yaron S, Yechiam H, BdolahAbram T, Greenfield C, Goldman-Wohl D, Milwidsky A, Rana S, Karumanchi SA, Yagel S. Relationship between nulliparity and preeclampsia may be explained by altered circulating soluble fms-like tyrosine kinase 1 . Hypertension in pregnancy. 2014 May 1; 33(2):250-9. https://doi.org/10.3109/10641955.2013.858745

24. Berhe AK, Kassa GM, Fekadu GA, Muche AA. Prevalence of hypertensive disorders of pregnancy in Ethiopia: a systemic review and meta-analysis. BMC pregnancy and childbirth. 2018 Dec; 18(1):34. https://doi.org/10.1186/s12884-018-1667-7

25. Melese MF, Badi MB, Aynalem GL. Perinatal outcomes of severe preeclampsia/eclampsia and associated factors among mothers admitted in Amhara Region referral hospitals, North West Ethiopia, 2018. BMC research notes. 2019 Dec; 12(1):147. https://doi.org/10.1186/s13104-019-4161-z

26. Weiler J, Tong S, Palmer KR. Is fetal growth restriction associated with a more severe maternal phenotype in the setting of early onset pre-eclampsia? A retrospective study. PLoS One. 2011 Oct 28; 6(10):e26937. https://doi.org/10.1371/journal.pone.0026937

27. Özkara A, Kaya AE, Başbuğ A, Ökten SB, Doğan O, Çağlar M, et al. Proteinuria in preeclampsia: is it important? Ginekol Pol. 2018; 89(5):256-61 https://doi.org/10.5603/GP.a2018.0044

28. Valdés E, Sepúlveda-Martínez Á, Tong A, Castro M, Castro D. Assessment of Protein:Creatinine Ratio versus 24-Hour Urine Protein in the Diagnosis of Preeclampsia. Gynecol Obstet Invest. 2016; 81(1):78-83. https://doi.org/10.1159/000381773

29. Robert M, Sepandj F, Liston RM, Dooley KC. Random ProteinCreatinine Ratio for the Quantitation of Proteinuria in
Pregnancy. Obstet Gynecol. 1997 Dec 1; 90(6):893-5. https://doi.org/10.1016/S0029-7844(97)00536-X

30. Durnwald C, Mercer B. A prospective comparison of total protein/creatinine ratio versus 24-hour urine protein in women with suspected preeclampsia. Am J Obstet Gynecol. 2003 Sep; 189(3):848-52. https://doi.org/10.1067/S00029378(03)00849-4

31. Shahbazian N, Hosseini-Asl F. A comparison of spot urine protein-creatinine ratio with 24-hour urine protein excretion in women with preeclampsia. Iran J Kidney Dis. 2008; 2(3):127-31.

32. Aggarwal N, Suri V, Soni S, Chopra V, Kohli HS. A Prospective Comparison of Random Urine Protein-Creatinine Ratio vs 24hour Urine Protein in Women With Preeclampsia. Medscape J Med. 2008 Apr 22; 10(4):98.

33. Demirci O, Kumru P, Arınkan A, Ardıç C, Arısoy R, Tozkır E, et al. Spot protein/creatinine ratio in preeclampsia as an alternative for 24-hour urine protein. Balk Med J. 2015 Jan; 32(1):51-5. https://doi.org/10.5152/balkanmedj.2015.15447

34. Kucukgoz Gulec U, Sucu M, Ozgunen FT, Buyukkurt S, Guzel AB, Paydas S. Spot Urine Protein-to-Creatinine Ratio to Predict the Magnitude of 24-Hour Total Proteinuria in Preeclampsia of Varying Severity. J Obstet Gynaecol Can JOGC J Obstet Gynecol Can JOGC. 2017 Oct; 39(10):854-60 https://doi.org/10.1016/j.jogc.2017.04.035

35. Waugh J, Hooper R, Lamb E, Robson S, Shennan A, Milne F, Price C, Thangaratinam S, Berdunov V, Bingham J. Spot proteincreatinine ratio and spot albumin-creatinine ratio in the assessment of pre-eclampsia: a diagnostic accuracy study with decision-analytic model-based economic evaluation and acceptability analysis. Health technology assessment (Winchester, England). 2017 0ct; 21(61):1. https://doi.org/10.3310/hta21610

36. Obeid N, O'Kelly R, Saadeh FA. A comparison of spot urine protein-creatinine ratio with 24 hour urine protein excretion for prediction of proteinuria in preeclampsia. Res Rep Gynaecol Obstet. 2018; 2 (1):11-15

37. Montero N, Soler MJ, Pascual MJ, Barrios C, Márquez E, Rodríguez E, et al. Correlation between the protein/creatinine ratio in spot urine and 24-hour urine protein. Nefrol Publicacion Of Soc Espanola Nefrol. 2012 Jul 17; 32(4):494-501.

38. Bejjani L, Nedellec S, Taïeb J, Thervet E, Benachi A. [Spot urinary protein to creatinine ratio: Which role in preeclampsia diagnosis?]. J Gynecol Obstet Biol Reprod (Paris). 2015 Nov; 44(9):795-801. https://doi.org/10.1016/j.jgyn.2015.04.006 
